\title{
New luminescence ages reveal Early to Middle Weichselian deposits in central Latvia
}

\author{
Kristaps LAMSTERS ${ }^{1, *}$, Edyta KALIŃSKA-NARTIŠA ${ }^{2}$, Vitālijs ZELČS ${ }^{1}$ and Helena ALEXANDERSON² \\ 1 University of Latvia, Faculty of Geography and Earth Sciences, Jelgavas Street 1, LV-1004, Riga, Latvia \\ 2 Lund University, Department of Geology, Sölvegatan 12, 22362 Lund, Sweden
}

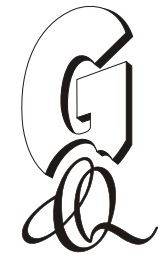

\begin{abstract}
Lamsters, K., Kalińska-Nartiša, E., Zelčs, V., Alexanderson, H., 2017. New luminescence ages reveal Early to Middle Weichselian deposits in central Latvia. Geological Quarterly, 61 (2): 480-490, doi: 10.7306/gq.1349

New optically stimulated luminescence (OSL) ages show that sandy deposits overlain by Late Weichselian subglacial till in central Latvia are of Early to Middle Weichselian age. The finer chronological resolution of unconsolidated sediment deposition in the Central Latvian Lowland (CLL) remains relatively unstudied, and here we provide a first characterisation of the deposits with respect to their age. Three OSL ages ranging between $84 \pm 9 \mathrm{ka}$ and $112 \pm 11 \mathrm{ka}$ suggest that the deposits studied in the CLL are of Early Weichselian age (MIS 5). We found no Middle Weichselian deposits in the CLL, and assume that any such younger sediments might have been eroded during the advance of the Zemgale Lobe in the Late Weichselian. One site, in the ice-marginal zone adjacent to the interlobate area, has nevertheless deposits dated to $44 \pm 10 \mathrm{ka}$ corresponding to the Middle Weichselian (MIS 3). Our results are compatible with existing ESR ages on three sets of Portlandia arctica shells from the central part of the lowland; the shells had been incorporated into glacial deposits during later glacial advances. Finally, our findings largely support ice-free conditions during the Early and Middle Weichselian in the middle and southern part of central Latvia.
\end{abstract}

Key words: optically stimulated luminescence (OSL) dating, subglacial bedforms, Early Weichselian, Middle Weichselian, central Latvia.

\section{INTRODUCTION}

The chronology of the Weichselian Glaciation in central Latvia is not well established due to the lack of reliable absolute dating. No optically stimulated luminescence (OSL) dates of Early and Middle Weichselian age have until now been available for central Latvia (cf. Zelčs et al., 2011), and only a few OSL ages reflecting Middle Weichselian time have been reported from other localities in Latvia (Zelčs et al., 2011; Saks et al., 2012). Some radiocarbon dates are known but they are questionable because of possible contamination (Dreimanis and Zelčs, 1995). Electron spin resonance (ESR) ages of Portlandia arctica shells redeposited in glacial sediments of the Central Latvian Lowland (CLL) during glacial advances range from $86.0 \pm 6.8 \mathrm{ka}$ (till) to $105.0 \pm 9.2 \mathrm{ka}$ (gravel) (Molodkov et al., 1998). The deglaciation history has also been investigated by cosmogenic ${ }^{10} \mathrm{Be}$ age determination (Rinterknecht et al., 2006, 2008) but this method suffers from insufficient resolution that renders difficult accurate correlation and separation of ice-marginal formations.

OSL dating presents an opportunity to date the dominant constituents of the deposits themselves (Thrasher et al., 2009),

* Corresponding author, e-mail: kristaps.lamsters@gmail.com

Received: July 9, 2016; accepted January 19, 2017; first published online: March 9, 2017 particularly of those that are sandy. These deposits, therefore, constitute suitable material for chronological studies. The OSL method has been frequently used in the last decade to obtain the age of glacioaquatic, fluvial, lacustrine and aeolian deposits in the Baltic region (Kalm, 2006; Molodkov et al., 2010; Rattas et al., 2010; Raukas et al., 2010; Zelčs et al., 2011; Saks et al., 2012; Satkūnas and Grigienè, 2012; Baltrūnas et al., 2013; Kalińska-Nartiša et al., 2015a, b, 2016). Despite this, questionable OSL ages have been frequently obtained from glaciolacustrine and glaciofluvial deposits (e.g., Raukas et al., 2010). A possible cause for this is incomplete bleaching of sand grains due to rapid deposition, turbulent streams, sedimentation in darkness or significant water turbidity (cf. Weckwerth et al., 2013). The results of previous investigations of Pleistocene chronology and particularly of the deglaciation of the last glaciation (Guobytè, 2004; Zelčs and Markots, 2004; Kalm, 2006, 2012; Rinterknecht et al., 2006, 2008; Raukas et al., 2010; Guobytė and Satkūnas, 2011; Zelčs et al., 2011; Lasberg and Kalm, 2013) indicate unresolved stratigraphic issues, such as the lack of the sufficiently accurate ages of Late Pleistocene deposits, particularly of Early and Middle Weichselian age.

To improve the chronology of the Weichselian Glaciation in central Latvia, we dated the sands overlain by Late Weichselian till with OSL. Mostly, these sands are found within the cores of subglacial bedforms (deposition of sandy sediments preceded the formation of subglacial bedforms) in the area of the Zemgale Ice Lobe (Lamsters and Zelčs, 2015), and one sample comes from an interlobate area; these deposits have not been previously investigated by luminescence methods. The issues 
concerning OSL dating of questionably well-bleached sediments as well as the chronological consequences of the ages are discussed.

\section{STUDY AREA AND STRATIGRAPHY}

\section{GEOLOGICAL SETTING}

Our study area is located in the central part of Latvia (Fig. 1) comprising the CLL, and it lies within the inner peripheral zone of the last Fennoscandian Ice Sheet (Straume, 1979; Āboltinš, 1989; Zelčs and Markots, 2004). The CLL is a glaciodepression of divergent type, which is linked with the central Latvian bedrock depression (Zelčs, 1993). The CLL experienced considerable glacial erosion through the Pleistocene glaciations that resulted in a relatively thin Quaternary succession - on average of $10-20 \mathrm{~m}$ and up to $20-40 \mathrm{~m}$ only below the highest glacial landforms (Juškevičs, 2000, 2001; Meirons, 2002). The deposits are thinner in the central part of the CLL, $<10 \mathrm{~m}$ and, in some places, only a few metres thick (Juškevičs, 2000, 2001; Meirons, 2002; Zelčs and Markots, 2004).

The glacial landsystems in the CLL were generally formed during the North (Linkuva in Latvia) and Middle Lithuanian (Gulbene in Latvia) glacial phases of the Late Weichselian Glaciation, when the Zemgale Ice Lobe of the Riga Ice Stream (Āboltinsš et al., 1977) was re-activated during the deglaciation. The divergent flow character of the Zemgale Ice Lobe is dem- onstrated by the orientation of streamlined bedforms (Lamsters and Zelčs, 2015). The present-day topography is dominated by radial and transverse subglacial bedforms - mostly drumlins and ribbed moraines (Zelčs, 1993; Lamsters, 2012; Lamsters and Zelčs, 2015).

The bedrock in the CLL is composed of Upper Devonian Frasnian and Famennian sedimentary rocks: sandstone, siltstone, clay, dolomite, marl and gypsum, as well as of Middle Devonian terrigenous rocks in its NE part (Brangulis et al., 1998). The youngest Permian, Triassic and Jurassic terrigenous and carbonate rocks are distributed in the SW corner of the CLL (Brangulis et al., 1998). The bedrock surface, in general, dips towards the $\mathrm{N}$ in the direction of the Gulf of Riga. The altitude of bedrock surface varies from $110 \mathrm{~m}$ a.s.l. to $60 \mathrm{~m}$ b.s.l. at the southern end of the Gulf of Riga.

\section{QUATERNARY DEPOSITS}

The Quaternary deposits mainly consist of heterogeneous Late Weichselian till interlayered with and underlain by sandy deposits (Savvaitovs and Straume, 1963; Āboltinšs, 1963; Ginters, 1978; Juškevičs, 2000, 2001; Meirons, 2002). The existence of an older till of Saalian age has been confirmed in: (1) local bedrock depressions and palaeoincisions (Āboltinš̌, 1963; Juškevičs, 2000, 2001; Meirons, 2002), (2) glaciotectonic landforms below the youngest till beds (Dreimanis, 1935; Dreimanis and Zelčs, 1998, 2004), or (3) as intraclasts in the younger tills (Dreimanis, 1935). The petrographic and textural composition

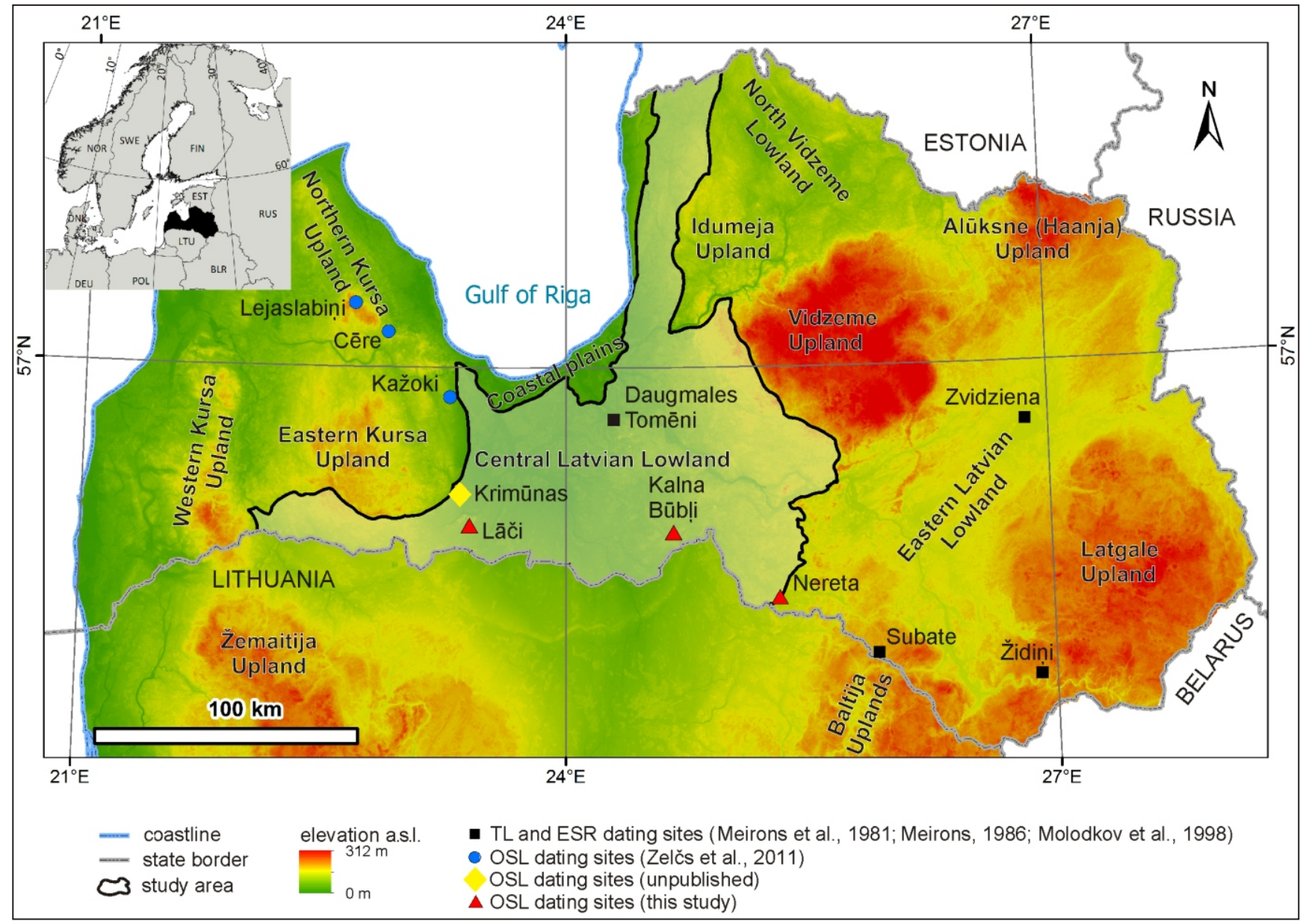

Fig. 1. The location of the study area (Central Latvian Lowland) and OSL sampling sites 
of till beds tends to be very similar (Mironovs et al., 1962; Āboltinsš, 1963; Ginters, 1978), thus their stratigraphic division is complicated and sometimes difficult to determine. The stratigraphic position of the tills is also poorly understood, because of the lack of qualitative dating results. For example, the upper dark-grey till bed was thought to have been deposited during the Saalian (Danilāns, 1973) in Western Latvia. A re-investigation in the western part of Latvia, however, revealed its Late Weichselian age (Saks et al., 2012). Thin and deformed grey till beds of unknown stratigraphic position have also been identified at several quarries in the CLL (Lamsters and Zelčs, 2015). A similar grey till has been found at the banks of the Daugava River near Daugmales Tomēni (see Fig. 1), located in a ribbed moraine, and it was interpreted as a Saalian till, because no Portlandia arctica shells were found (Dreimanis and Zelčs, 1995, 1998; Molodkov et al., 1998).

Commonly, the Pleistocene sequence in the CLL contains two or more till beds. For example, two Weichselian till beds interbedded with sorted deposits have been recognized in the area up-glacier of the North Lithuanian ice-marginal succession (Āboltinsš, 1963; Savvaitovs and Straume, 1963; Dreimanis and Zelčs, 1995; Zelčs and Markots, 2004). Three till beds have been found in local bedrock depressions (Ginters, 1978; Juškevičs, 2001), and up to four till beds have been reported from North Lithuania (Gaigalas and Marcinkevičius, 1982; Baltrūnas et al., 2005); the lower till bed has been attributed to the Grūda stadial (Gaigalas, 1995; Guobyte, 2004), which coincides with the maximum extent of the last Fennoscandian Ice Sheet. The upper till bed correlates with the Baltic stadial of the Late Weichselian Glaciation (Gaigalas, 1995; Guobyte, 2004). The highest number of lithologically different till beds (up to 5 ) has been found in a borehole at the western side of the Vidzeme Upland (Mironovs et al., 1962). Similar lithological differences are linked to glaciotectonically deformed till beds, for example at up-glacier slopes of ribbed moraines. Up to five stacked Late Weichselian till beds underlain by one or two possible Saalian till beds are frequently reported (Āboltiņš, 1989; Dreimanis and Zelčs, 1998, 2004; Lamsters and Zelčs, 2015). It is feasible that the younger till beds, which formed due to subglacial thrusting, are of the same age. It is well-established that glaciotectonic deformation played a significant role both in drumlin and ribbed moraine formation and in changing the original Pleistocene sediment bedding and thickness (Levkov, 1980; Äboltiņš, 1989; Zelčs, 1993). This is why interlayers of sorted deposits, rafts of pre-Late Pleistocene deposits and Devonian bedrock, and upwardly injected clastic dykes are common in the CLL (Dreimanis, 1935, 1992; Āboltinš̌, 1963; Zelčs, 1993), particularly in glaciotectonic landforms, for example, in ribbed moraines (Dreimanis and Zelčs, 1998, 2004) and on the proximal slopes and adjacent areas of the North Lithuanian ice-marginal successions (Āboltinsš, 1963).

The cover on top of the upper Late Weichselian till bed consists predominantly of 5-6 m thick glaciolacustrine deposits of the Baltic Ice Lake and younger coastal deposits in the proximity of the Gulf of Riga and a 2-3 m thick sequence of glaciolacustrine deposits of the Zemgale ice-dammed lake in the northern and central parts of the plains of the CLL. Additionally, 3-8 $\mathrm{m}$ thick glaciolacustrine deposits of the Daudzeva proglacial lake are distributed further to the south-east of the study area. Sandy aeolian sediments forming inland dunes occur in places (Juškevičs, 2000, 2001; Meirons, 2002).

GEOLOGICAL DESCRIPTION OF OSL SAMPLING SITES

Three localities with sandy deposits overlain by subglacial till of the Late Weichselian Glaciation were chosen to constrain their deposition in time and these are Lāči, Kalna Būbl̦i and Nereta (Fig. 1). All these sites are located in subglacial bedforms formed during the decay of the last Fennoscandian Ice Sheet. Lāči and Kalna Būbli are situated in the landforms (area covered by the Zemgale Ice Lobe), while Nereta is located in the glaciotectonised ice-marginal succession of the Middle Lithuanian glacial phase, which stretches along the western edge of the interlobate area between the Zemgale and Lubāns Ice Lobes. The deposition of sandy sediments occurred prior to formation of subglacial bedforms. The deposits represent undeformed cores of subglacial bedforms, which were formed due to erosion of pre-existing sorted sediments. Later, till was deposited and deformed (Lamsters and Zelčs, 2015). The depositional environment of the sampled sandy deposits is likely fluvial or glaciofluvial: see site descriptions below.

In the Lāči Quarry, up to $3 \mathrm{~m}$ thick reddish-brown subglacial till covers fine to medium-grained sand. The horizontal-laminated sand was subjected to OSL sampling at $4.7 \mathrm{~m}$ and $9.2 \mathrm{~m}$ depth (Fig. 2A, B). The Lāči Quarry is located in a drumlin (Lamsters and Zelčs, 2015), the core of which consists mainly of fine- and medium-grained sand. The most frequent lithofacies are planar cross-bedded, trough cross-bedded, horizontal-laminated and climbing ripple cross-laminated sand. Horizontal-laminated sand, which was sampled, is thought to have been deposited from rapid streams in the upper flow regime. The composition and texture of the sorted deposits at the Lāči Quarry and their lithofacies suggest deposition from streams in a fluvial or shallow basin environment, although we also cannot exclude glaciolacustrine sedimentation in a basin with high sediment supply and fluvial activity.

A similar fine sand sequence was sampled at a depth of $5 \mathrm{~m}$ at Kalna Būbli (Fig. 2D). The Pleistocene sequence here consists of horizontally-laminated, planar and trough cross-bedded sandy and occasionally gravelly deposits indicating deposition by moderately rapid streams. The sorted deposits are overlain by Weichselian subglacial till. The till is interbedded with deformed sandy deposits and is locally boudinaged, which results in a discontinuous till layer, which is thought to have been deformed subglacially during the formation of ribbed moraine. The topmost part of the section consists of $1.5 \mathrm{~m}$ of varved clay that directly covers the till unit. This clay is thought to have been deposited in a local basin after the formation of the ribbed moraine.

In the Nereta Quarry, sampling was carried out in fine sand at $5.5 \mathrm{~m}$ depth. Here, the Pleistocene sequence consists of a succession of till and sand layers underlain by massive and horizontally-laminated sand. The upper part of Pleistocene succession was deposited as thrust sheets in ice-marginal conditions between the advancing Lubāns and Zemgale ice lobes, but the age of deposition of the sampled sand is unknown.

\section{METHODOLOGY}

All luminescence dating samples were collected from four sites by hammering opaque plastic tubes into freshly cleaned exposure surfaces using the Eijkelkamp Sampler Set for Hard Soils sampling kit. Samples were taken in opaque plastic tubes to avoid exposure to daylight while sampling. Along with the OSL samples, sediment water content was assessed in the field using a ThetaProbe Soil Moisture Sensor. Four sediment samples (two from Lāči, one from Kalna Būblli and one from Nereta) were treated under darkroom conditions at the Lund Luminescence Laboratory (LLL), Lund, Sweden and a detailed description can be found in the following subchapters (see location of OSL sampling sites in Fig. 1). Two samples from the 

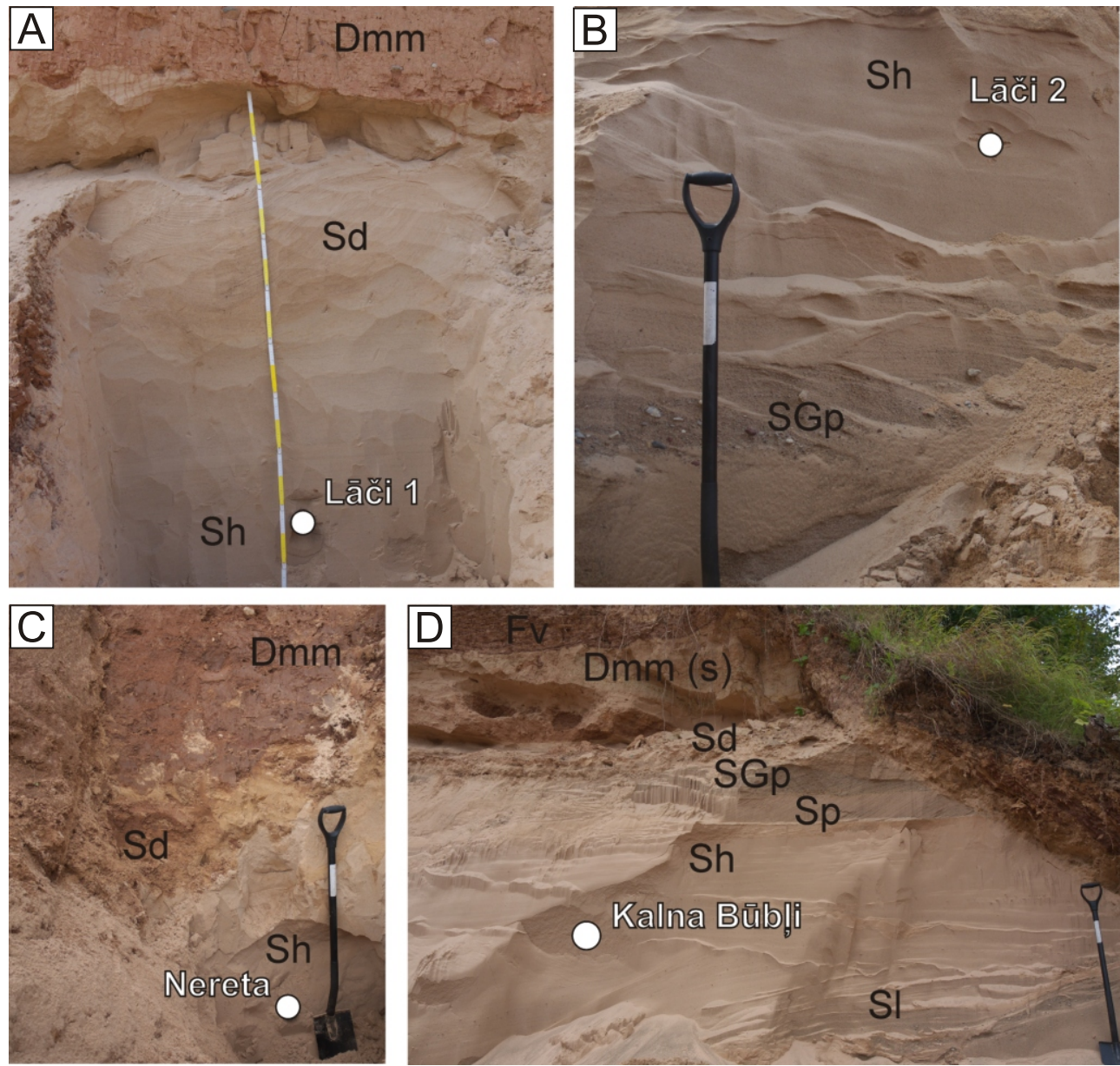

Fig. 2. The sedimentary structures observed at the Lāči (A, B), Nereta (C) and Kalna Būbļi (D) OSL sampling sites

Dmm - diamicton, matrix supported, massive; Dmm (s) - diamicton, matrix supported, massive, sheared; Sd - sand, deformed; SI - sand with low-angle inclined stratification; Sh - sand, horizontally bedded; Sp -sand, planar cross-bedded; SGp -sandy gravel, planar cross-bedded; Fv - varved clay (lithofacies codes adapted from Miall, 1978 and Eyles et al., 1983)

Krimūnas Quarry were analysed at the Finnish Museum of Natural History (FMNH), Helsinki, Finland, and since we can provide only a limited methodological background and dataset (Oinonen and Eskola, 2009), they are treated as unpublished data and are only used for comparison in the Interpretation and Discussion.

\section{SAMPLE PREPARATION AND MEASUREMENT}

The samples in opaque plastic tubes were opened under darkroom conditions. The sediment at each end of the tubes which might have been exposed to daylight while sampling, was retained to determine the dose rate and the water content. Only material from the inner part of the tube was taken for $D_{e}$ measurements. The 180-250 $\mu \mathrm{m}$ fraction was extracted by wet sieving. After that, sample preparation included treatment with $10 \% \mathrm{HCl}$ for $30 \mathrm{~min}$. and $10 \% \mathrm{H}_{2} \mathrm{O}_{2}$ for $15 \mathrm{~min}$. to dissolve carbonates and organic material, respectively. Heavy liquid (LST Fast Float) with a density of $2.62 \mathrm{~g} / \mathrm{cm}^{3}$ was used to separate quartz and feldspars. The extracted quartz samples were treated with $38 \%$ hydrofluoric acid (HF) for $60 \mathrm{~min}$, and further re-treated with $10 \% \mathrm{HCl}$ for $40 \mathrm{~min}$. to remove possible fluoride contamination. Finally, the purified quartz samples were re-sieved with a $180 \mu \mathrm{m}$ sieve before measurement.

At the LLL an automated Ris $\varnothing$ TL/OSL reader DA-20 equipped with a calibrated ${ }^{90} \mathrm{Sr} /{ }^{90} \mathrm{Y}$ beta radiation source (dose rate $\sim 0.15 \mathrm{~Gy} \mathrm{~s}^{-1}$ ), blue and infrared (IR) LED (light emitting diode) lamps, and U-340 glass filter $7.5 \mathrm{~mm}$ thick was used for measurements (Bøtter-Jensen et al., 2000).

\section{WATER CONTENT AND DOSIMETRY}

Water content was determined by weighing a subsample from the OSL-tube, when taken out from the tube (= natural water content) when saturated (after $24 \mathrm{~h}$ covered by water) and when dry (after $24 \mathrm{~h}$ at $105^{\circ} \mathrm{C}$ ) and further calculating the natural and saturated water content as weight percent. The dose rate subsamples were dried, ignited $\left(24 \mathrm{~h}\right.$ at $\left.450^{\circ} \mathrm{C}\right)$, homogenised and cast in wax in a fixed geometry. Prior to radionuclide concentration measurements, the casts were stored for at least three weeks (Murray et al., 1987). A high-resolution gamma spectrometer at the Nordic Laboratory for Luminescence Dating, Risø, Denmark, was used. The radionuclide concentrations have been converted into beta and gamma dose rates following Olley et al. (1996). 
PURITY OF THE QUARTZ EXTRACTS

In a first test, quartz extracts were prepared as large $(8 \mathrm{~mm})$ aliquots and two aliquots per sample were stimulated with infrared light to identify possible feldspar contamination. It is considered that the sensitivity to infrared stimulation is significant when the OSL IR depletion ratio is more than $10 \%$ of the blue signal (Duller, 2003), which was the case for all of our samples. In order to obtain a purer quartz signal, a post-IR blue Single Aliquot Regenerative (SAR) protocol (Banerjee et al., 2001) was applied. Between 24 and 29 aliquots were measured for each sample to obtain the equivalent dose $\left(D_{e}\right)$.

\section{DOSE RECOVERY PREHEAT PLATEAU AND PREHEAT PLATEAU TESTS}

Three aliquots per temperature from one representative sample (Lāči 1) were used to calculate the dose recovery ratio at different preheat temperatures. In that way, eighteen aliquots covered the preheat range of 180 to $280^{\circ} \mathrm{C}$ with an interval of $20^{\circ} \mathrm{C}$. Cut heat was kept at $20^{\circ} \mathrm{C}$ lower than the preheat. Only the preheat temperatures at which the dose recovery ratio were within $10 \%$ of unity are considered acceptable. The results show that preheat at $220^{\circ} \mathrm{C}$ seems to be the most suitable for the Lāči 1 sample (Fig. 3A). To complement the results of dose-recovery preheat plateau, which could be misleading (Roberts, 2006), we also carried out a standard preheat plateau test. Following this, three aliquots of the same sample and with the same temperature settings were used. From this test, temperature ranges from 200 to $240^{\circ} \mathrm{C}$ show a plateau and the $D_{e}$ value at $220^{\circ} \mathrm{C}$ reveals the smallest uncertainty. Combining the two tests, the preheat temperature of $220^{\circ} \mathrm{C}$ should be used in further analyses.

\section{DOSE RECOVERY TEST}

To test whether the measurement protocol was suitable for the other samples, a dose recovery test was conducted on all samples. Six aliquots per sample were bleached in daylight on a windowsill for a few days, and then additionally stimulated using blue LED exposure for $60 \mathrm{~s}$ to empty the previous OSL signal. The average measured to given dose ratio was $0.94 \pm 0.02$, $1.04 \pm 0.10$ and $1.09 \pm 0.06$ for samples Lāči 1,2 and Nereta, respectively (Table 1 ), thus implying that the protocol is able to measure accurately a dose given before thermal pre-treatment (Wintle and Murray, 2006). A higher ratio of $1.13 \pm 0.10$ was obtained for the Kalna Būbli sample indicating an unsuitable preheat temperature. After an additional standard preheat plateau test for that sample based on six aliquots (Fig. 3B), we adopted a preheat temperature of $200^{\circ} \mathrm{C}$ and a cut heat of $180^{\circ} \mathrm{C}$. The dose recovery test for that temperature gave an acceptable ratio of $0.94 \pm 0.060(n=6)$.

\section{DATA ANALYSIS}

Risø Analyst 4.10 software was used to calculate equivalent doses $\left(D_{e}\right)$; only aliquots with test dose error $<10 \%$, a recycling ratio within $10 \%$ of unity, and a signal more than three sigma above the background were accepted. Recycled points were used for exponential-linear fitting and the growth curve was forced through the origin. The fast-component-dominated OSL signal was isolated from the first part of the decay curve, so that the time intervals of $0.08-0.32 \mathrm{~s}$ and $0.48-1.08 \mathrm{~s}$ were used for peak and background signals, respectively. By using

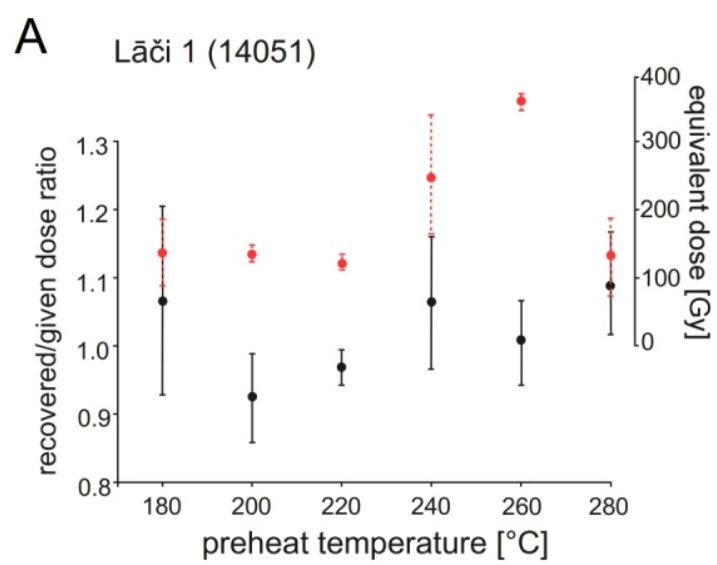

B Kalna Būbli (14054)

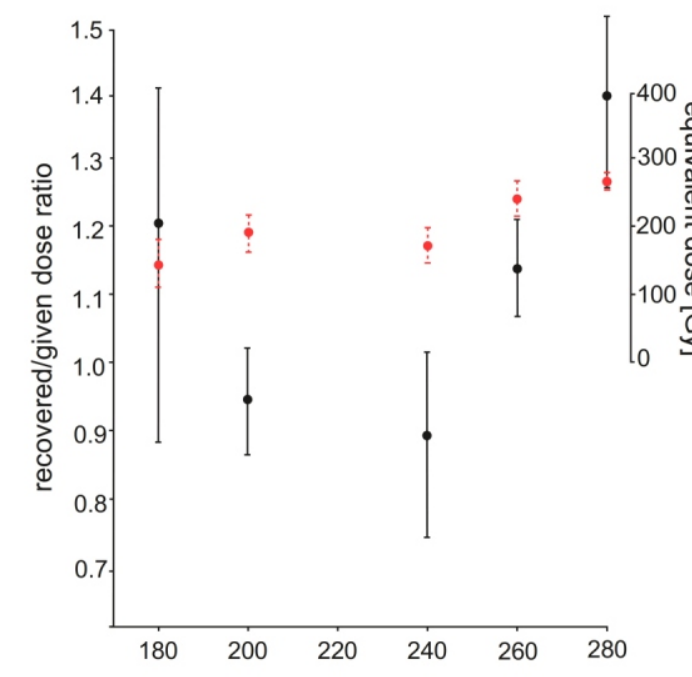

Fig. 3. Dose recovery ratio at different preheat temperatures (in black) and preheat plateau test (in red) for (A) the Lāči 1 (14051) sample, and (B) the Kalna Būblli (14054) sample excluding a temperature of $220^{\circ} \mathrm{C}$

an early background subtraction, any influence of medium and slow signal components was minimized (Ballarini et al., 2007).

The overdispersion $(O D)$ was calculated using an excel macro by S. Huot based on the Central Age Model (Galbraith et al., 1999). Finally, we used the three-parameter minimum-age model (MAM-3; Galbraith et al., 1999) following the first criterion of the single-aliquot decision protocol of Arnold et al. (2007), and this was fulfilled by samples from Nereta and Kalna Būbli. For the two Lāči samples the Central Age Model (CAM) was applied.

\section{RESULTS}

WATER CONTENT AND DOSE RATE

The natural and saturated water content ranges between $0.2-3.5 \%$ and $24.4-27.9 \%$, respectively (Table 1). All these values seem to be rather unlikely as average water content since deposition. Field measurement of the water content reveals, in 
Summary of radionuclide concentrations, water contents, total dose rates and dose recovery ratios

\begin{tabular}{|l|c|c|c|c|c|c|c|c|c|c|}
\hline Field ID & LLL ID & $\begin{array}{c}{ }^{238} \mathrm{U} \pm \text { s.e. } \\
{[\mathrm{Bq} / \mathrm{kg}]}\end{array}$ & $\begin{array}{c}{ }^{226} \mathrm{Ra} \pm \mathrm{s.e} . \\
{[\mathrm{Bq} / \mathrm{kg}]}\end{array}$ & $\begin{array}{c}{ }^{232} \mathrm{Th} \pm \mathrm{s.e.} \\
{[\mathrm{Bq} / \mathrm{kg}]}\end{array}$ & $\begin{array}{c}{ }^{40} \mathrm{~K} \pm \mathrm{s.e} . \\
{[\mathrm{Bq} / \mathrm{kg}]}\end{array}$ & $\begin{array}{c}\text { w.c. field/ } \\
\text { natural }[\%]\end{array}$ & $\begin{array}{c}\text { w.c. sat. } \\
{[\%]}\end{array}$ & $\begin{array}{c}\text { w.c. } \\
{[\%]}\end{array}$ & $\begin{array}{c}\text { Total dose } \\
\text { rate } \pm \text { S.e. } \\
{[\mathrm{Gy} / \mathrm{ka}]}\end{array}$ & $\begin{array}{c}\text { Dose } \\
\text { recovery }\end{array}$ \\
\hline Lāči 1 & 14051 & $-3.36 \pm 8.71$ & $7.36 \pm 0.63$ & $7.25 \pm 0.59$ & $366 \pm 14$ & $3.5 / 3.5$ & 27.9 & $9 \pm 4$ & $1.36 \pm 0.07$ & $0.94 \pm 0.02$ \\
\hline Lāči 2 & 14052 & $4.93 \pm 5.28$ & $9.35 \pm 0.39$ & $11.52 \pm 0.37$ & $361 \pm 8$ & $8.5 / 1.9$ & 24.4 & $9 \pm 4$ & $1.42 \pm 0.07$ & $1.04 \pm 0.10$ \\
\hline Nereta & 14053 & $-1.70 \pm 8.00$ & $10.27 \pm 0.61$ & $11.47 \pm 0.57$ & $421 \pm 14$ & $4.2 . / 0.2$ & 25.6 & $9 \pm 4$ & $1.60 \pm 0.08$ & $1.09 \pm 0.06$ \\
\hline $\begin{array}{l}\text { Kalna } \\
\text { Būblji }\end{array}$ & 14054 & $-4.04 \pm 7.57$ & $9.91 \pm 0.57$ & $12.65 \pm 0.53$ & $395 \pm 12$ & $3.4 / 1.3$ & 24.6 & $9 \pm 4$ & $1.54 \pm 0.08$ & $0.94 \pm 0.06$ \\
\hline
\end{tabular}

s.e. - standard error; w.c. - water content

contrast, values between 3.4 and $8.5 \%$ (Kalna Būbli and Lāči 2 respectively). We, therefore, estimated a lifetime average burial water content of $9 \pm 4 \%$ for all samples, assuming that saturated water conditions occurred for approximately less than half of the burial time. The uncertainty takes into account inevitable fluctuations in water content with time. A narrow range of dose rates between $1.36 \pm 0.07 \mathrm{~Gy} / \mathrm{ka}$ and $1.6 \pm 0.08 \mathrm{~Gy} / \mathrm{ka}$ (for Lāči 1 and Nereta, respectively) was obtained.

\section{LUMINESCENCE SIGNAL CHARACTERISTICS}

The luminescence signal is dominated by the fast OSL component that can be detected from the fast decay (cf. decay curve for Lāči 1 sample, Fig. 4). However, medium-to-slow components also occur in some aliquots and this can be detected in the Nereta sample (Fig. 4). Although two growth curves reveal an acceptable recycling and low recuperation (Fig. 4), occasionally the limits of both recycling and recuperation were exceeded. The average recycling ratio is $1.01 \pm 0.004$ $(n=102)$ and the average recuperation is $0.8 \pm 0.2(n=102)$.

\section{DOSE DISTRIBUTION AND AGE CALCULATION}

Equivalent dose $\left(D_{e}\right)$ distributions for individual samples are broad; the difference between the lowest and the highest aliquot $D_{e}$ is $90-290$ Gy (Fig. 5). The mean $D_{e}$ is $152 \pm 13$ Gy, $131 \pm 11,90 \pm 8$ Gy and $144 \pm 13$ Gy (Lāči 1, Lāči 2, Nereta and Kalna Būblji, respectively). Whereas the Lāči 1 dose distribution is symmetrical, for the other samples the distributions are either slightly negatively skewed ( $S k=-0.2$ at Lāči 2$)$ or significantly positively skewed ( $S k=1.4$ and 1.1 at Nereta and Kalna Būbli, respectively; Fig. 5). For all samples, a high overdispersion $(O D)$ was obtained (42-46\%; Table 2). Both the central (CAM) and minimum-age model (MAM-3) doses stay in good agreement with mean $D_{e}$, although being slightly younger.

The four final OSL ages (Table 2) obtained from the LLL fall into three groups that vary between $56 \pm 6 \mathrm{ka}$ and $112 \pm 11 \mathrm{ka}$

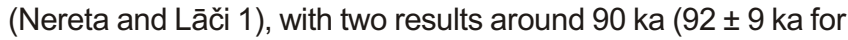
Lāči 2 and $93 \pm 10$ ka for Kalna Būbli). The CAM and MAM-3 ages, in contrast, show ranges of $82 \pm 10 \mathrm{ka}$ and $102 \pm 12 \mathrm{ka}$ (Lāči 1 and 2), and $44 \pm 10$ ka and $84 \pm 9$ ka (Nereta and Kalna Būblji).

\section{INTERPRETATION}

The routine tests of assumption i.e. dose recovery test (cf. Results; Table 1) reveal that the SAR protocol can successfully measure a given laboratory dose. We are thus confident that
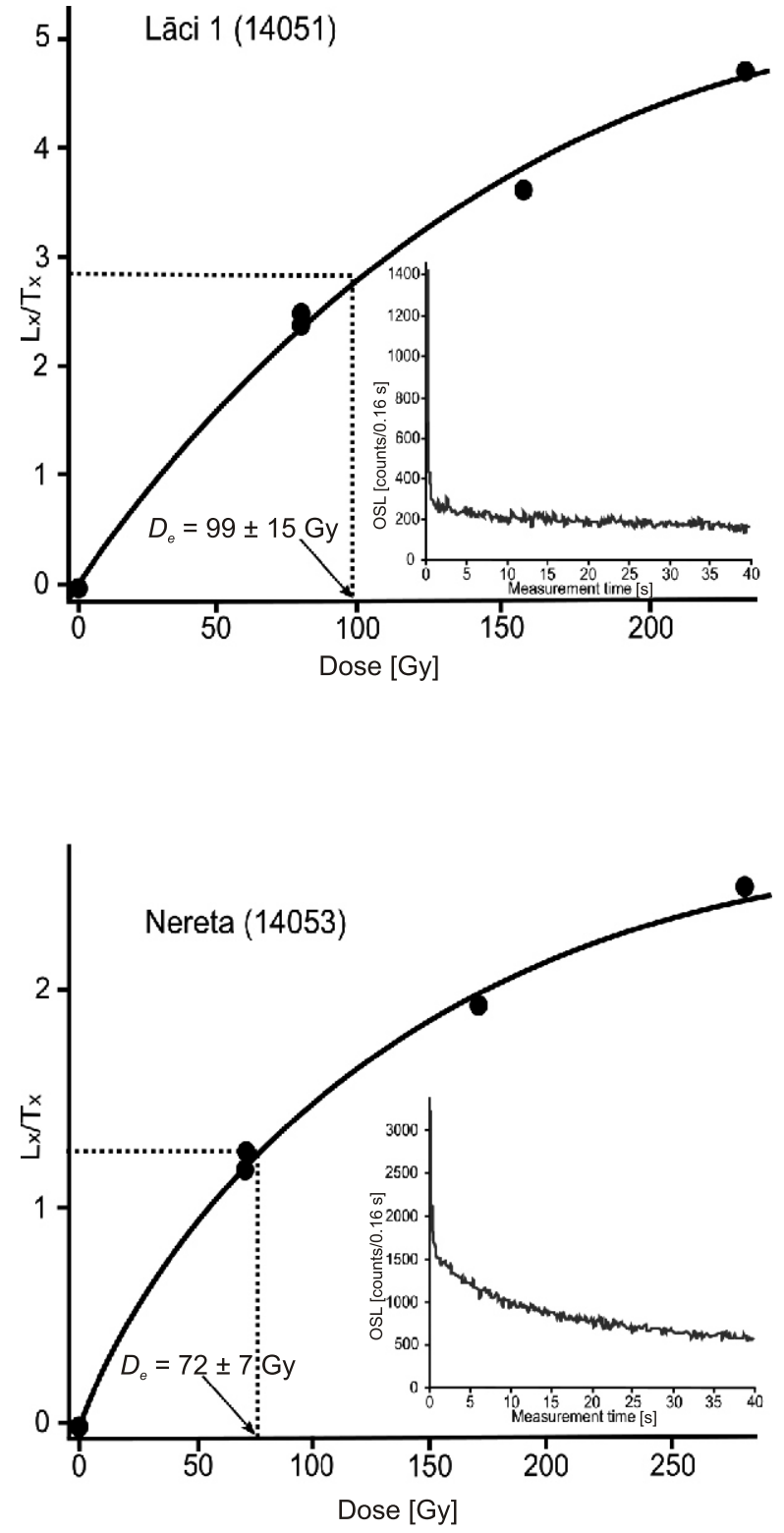

Fig. 4. Examples of growth and decay curves for the Lāči 1 (14051) and Nereta (14053) samples 

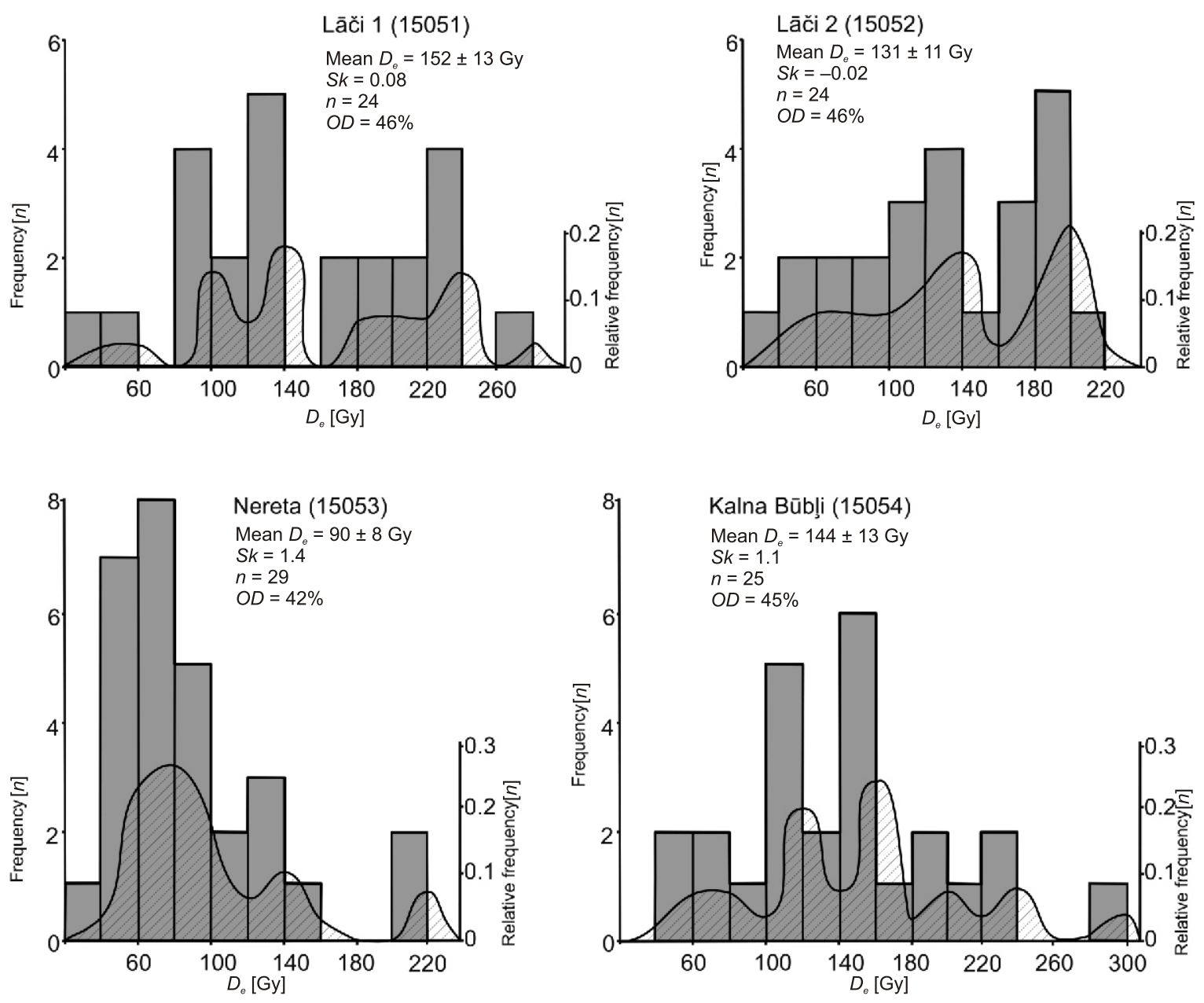

Fig. 5. Dose distribution and density probability function of the samples investigated

Summary of equivalent doses $\left(D_{e}\right)$ and ages

\begin{tabular}{|l|c|c|c|c|c|c|c|c|}
\hline Field ID & Lab ID* & $n$ & $\begin{array}{c}D_{e} \pm \text { s.e. } \\
{[\text { Gy] }}\end{array}$ & $\begin{array}{c}\text { Age } \pm \text { s.e. } \\
{[\mathrm{ka}]}\end{array}$ & $\begin{array}{c}\text { Depth of } \\
\text { sample }\end{array}$ & $\begin{array}{c}D_{e} \pm \text { s.e. } \\
\left(\mathrm{CAM}{ }^{* *} \text { or MAM-3; Gy }\right)\end{array}$ & $\begin{array}{c}\text { Age } \pm \text { S.e. } \\
\left(\text { CAM }^{* *} \text { or MAM-3; ka }\right)\end{array}$ & $p$ \\
\hline Lāči 1 & Lund-14051 & 24 & $152 \pm 13$ & $\mathbf{1 1 2} \pm \mathbf{1 1}$ & 4.7 & $138 \pm 14^{* *}$ & $102 \pm 12^{* *}$ & - \\
\hline Lāči 2 & Lund-14052 & 24 & $131 \pm 11$ & $\mathbf{9 2} \pm \mathbf{9}$ & 9.2 & $117 \pm 12^{* *}$ & $82 \pm 10^{* *}$ & - \\
\hline Nereta & Lund-14053 & 29 & $90 \pm 8$ & $56 \pm 6$ & 5.5 & $70 \pm 16$ & $\mathbf{4 4 \pm 1 0}$ & 0.9 \\
\hline $\begin{array}{l}\text { Kalna } \\
\text { Būbli }\end{array}$ & Lund-14054 & 25 & $144 \pm 13$ & $93 \pm 10$ & 5.0 & $130 \pm 13$ & $\mathbf{8 4} \pm \mathbf{9}$ & 0.9 \\
\hline
\end{tabular}

* - Lund Luminescence Laboratory, Sweden; ** - samples in which the CAM was used; $n$ - number of aliquots measured to obtain average $D_{e}$ 's; s.e. - standard error; $p$ - probability values; the most reliable ages are in bold

the good accuracy of each $D_{e}$ 's is produced by the SAR protocol. However, a few potential issues need to be addressed.

Water and glacier-transported sediments, due to their depositional environment, tend to suffer from incomplete bleaching (cf. Rodnight et al., 2006; Fuchs and Owen, 2008; Alexanderson and Håkansson, 2014; King et al., 2014; Mehta et al., 2014). A single-aliquot approach reported evidence of an asymmetrical $D_{e}$ distribution (cf. Results) that is likely due to the presence of poorly bleached grains in the sample (Thrasher et al., 2009). Because the samples from the Nereta and Kalna Būbli quarries have clearly asymmetrical and largely positively skewed $D_{e}$ distributions (Fig. 5), poorly bleached quartz grains seem to contribute to the dose here. Considering, however, the old OSL ages of the deposits, the effect of incomplete bleaching 
is usually expected to be small (Murray and Olley, 2002). Additionally, the effect of a few poorly bleached grains, in case where the majority of the grains are bleached, is rather small (Alexanderson and Murray, 2012).

The overdispersion $(O D)$ value, which reflects the spread of multiple independent $D_{e}$ estimates from aliquots (Thomas and Burrough, 2013) can also be used to characterise the depositional environment. For example, to indicate factors such as insufficient exposure to sunlight prior to burial (Olley et al., 1996), post-depositional mixing of grains (Jacobs, 2008), recent erosion from the bedrock (Lukas et al., 2007) or microdosimetry in heterogeneous and coarse-grained deposits (Klasen et al., 2007).

In this study, the $O D$ is high compared to e.g. well-bleached samples (Arnold and Roberts, 2009), and of a very similar value among the sites (Table 2). This can be explained by a similar opportunity of sediment bleaching and depositional conditions and/or source sediments. Combined with the asymmetrical nature of $D_{e}$ with large values of $O D$ of the deposits investigated, a partial bleaching of their grains cannot be rejected. However, these ages are based on large aliquot measurements, and thus even if incomplete bleaching was present, it is likely to be obscured by the effects of averaging between grains (Duller 2008). The ages suffer from relatively poor precision. This is likely due to the wide spread of equivalent dose distributions resulting in high $O D$ values. No data on $O D$ are available for similar sedimentary units at nearby sites, thus hindering a possible correlation. However, considering the wide spatial distribution of the sites investigated, such a high $O D$ value in all of them is thought to be due to the general luminescence nature of the deposits investigated, and local factors should be ruled out. Slightly tighter and more symmetrical dose distributions were found for the Lāči 1 and 2 samples, thus possibly suggesting their homogeneous bleaching (cf. Murray and Olley, 2002). Conversely, a wide and symmetrical $D_{e}$ distribution may indicate a large proportion of incompletely bleached grains (Wallinga, 2002). But whether or not the deposit at the Lāči site is incompletely bleached cannot be resolved at this stage of research. Limited results from the neighbouring Krimūnas site (unpubl. data; Oinonen and Eskola, 2009), however, largely coincide with the ages at the Lāči site and, therefore, to some extent argue for a well-bleached deposit at Lāči.

Mostly only fast signal components that reset quickly (Kuhns et al., 2000), and are quick to bleach under optical stimulation (Thrasher et al., 2009), dominate among the samples investigated (Fig. 4). Although Jain et al. (2003) reported on the dominance of the fast quartz component in most quartz samples, some studies, however, showed that sediments could suffer from a lack of the fast component, which results in the presence of difficult-to-bleach medium-to-slow components (Lukas et al., 2007). Some of the aliquots from the Nereta sample do show such medium-to-slow components (Fig. 4) but there is also a fast signal component present. In the rest of our samples the fast-signal component seems to be strong.

The MAM statistically selects the aliquots with the lowest $D_{e}$ 's, that is, those that were most probably sufficiently bleached (Wyshnytzky et al., 2015), and in this study provides 9-12 ka younger ages (Table 2); this is, however, within the error of presented mean ages. The probability $(p)$ value for the Nereta and Kalna Būbli samples is high and in these cases the MAM has produced reliable ages. This is additionally supported by the $D_{e}$ 's distribution, where the peaks are closer to the MAM value (Fig. 5). We therefore favour the MAM ages for the Nereta and Kalna Būbli. Ages obtained from the CAM (for the Lāči 1 and 2) are also younger (10 ka) and within error.
The water content in the deposit influences the dose rate and hence the final age (Wintle, 2008). If assuming the present-day water content as measured in the field (cf. Results) as an average water content, the age range for the 53-112 ka samples would be 53-106 ka, where the Lāči 2 sample would keep the same age. Conversely, considering the other extreme - saturated conditions - the range would become 65-131 ka. Resulting from this, most ages would be within error of the present selected ages and does not change our main conclusions of the age of the deposits. Only the age obtained from the Lâči 1 sample in saturated conditions is within two standard errors of the original age of $112 \pm 11 \mathrm{ka}$. The uncertainties in water-content estimates thus do not change our chronology significantly.

\section{DISCUSSION}

Our new OSL ages complement the Early and Middle Weichselian history of central Latvia by providing the time when ice-free conditions prevailed. The OSL ages from the Lāči and Kalna Būbli sites range between $84 \pm 9$ ka and $112 \pm 11$ ka and fall within marine isotope stage 5 (MIS 5). This corresponds to the Early Weichselian (117-75 ka after Mangerud, 1991, or 115-85 ka after Svendsen et al., 2004) in the North European chronostratigraphy.

Our findings in Latvia thus support data from Estonia and Lithuania by showing that during Early Weichselian time the Baltic territory experienced ice-free conditions at least from $115 \mathrm{ka}$ to $68 \mathrm{ka}$ (Kalm et al., 2011) or from $114.3 \pm 7.4$ to $76.5 \pm 4.9 \mathrm{ka}$ (Molodkov et al., 2010). The luminescence record from the Early Weichselian in Latvia is otherwise so far rather scarce, but the existing data is in agreement with our results. Lacustrine deposits overlain by Weichselian till in SE Latvia (Židinii) have been dated by thermoluminescence (TL) to 79 ka (Meirons et al., 1981). Lacustrine and fluvial deposits from Subate and Zvidziena (see Fig. 1 for location) revealed an age range between 92 and $97 \mathrm{ka}$ (Meirons, 1986). Of Early and Middle Weichselian age are also the glaciofluvial deposits at Lejaslabiņi and Cēre in northwestern Latvia (Zelčs et al., 2011), which yielded four luminescence ages of $85 \pm 5,42 \pm 3$, $115 \pm 10$ and $45 \pm 3 \mathrm{ka}$. Finally, at the Krimūnas site, located some $14 \mathrm{~km}$ north of the Lāči site, sediments were deposited at a similar time frame (101 $\pm 18 \mathrm{ka}$ and $95 \pm 15 \mathrm{ka}$; unpubl. data; Oinonen and Eskola, 2009).

The OSL age from the Nereta site (44 $\pm 10 \mathrm{ka})$, on the other hand, corresponds with the Middle Weichselian (MIS 3). During the Middle Weichselian a suggested glaciation in Latvia known as the Talsi stadial (Zelčs and Markots, 2004) could have reached western and northern Latvia between 68 ka and $54 \mathrm{ka}$ (Zelčs et al., 2011). It is most likely that this glacial event did not extend into the middle and southern part of the study area according to local (Zelčs et al., 2011) and regional reconstructions (Svendsen et al., 2004). According to modelling of the Weichselian Ice Sheet advances in the Baltic region by Holmlund and Fastook (1995), the first glacial advance into the Gulf of Riga was probably at about $64 \mathrm{ka}$. It eroded the upper part of the Eemian and Early Weichselian marine clay containing Portlandia arctica shells and assimilated these into the lowermost Weichselian till unit (Molodkov et al., 1998), which is exposed along the bluffs of the Daugava River Valley in the vicinity of Daugmale, northern CLL (Dreimanis and Zelčs, 1998, 2004).

In combination with the lack of evidence of younger glacial deposition in the middle and southern plains of CLL, it seems that no glaciation took place in this part of Latvia between the 
Eemian Interglacial and the Late Weichselian. Between 54 ka and 24 ka ice-free conditions persisted throughout all Latvia; this Middle Weichselian interstadial is locally named the Lejasciems interstadial (Zelčs and Markots, 2004). It is also suggested from Lithuanian studies that most likely the major part of the Eastern Baltic was not covered by ice until the Late Weichselian (Guobytè and Satkūnas, 2011). The ice-free period in Estonia was from at least 115 to 68 ka during the Early Weichselian and between 44 and 27 ka during the Middle Weichselian (Kalm et al., 2011).

During the long interval from the Early Weichselian to the beginning of the Late Weichselian, favourable conditions could have existed in central Latvia for the deposition of shallow basin and fluvial sediments, which have been dated in several localities elsewhere in Latvia and Lithuania (Satkūnas et al., 2009, 2013; Zelčs et al., 2011; Saks et al., 2012). The OSL-dated deposits in our study could reflect a similar environment, however, most of the ages presented in this study, with the exception of the Nereta sample, do not coincide with those of the other deposits (e.g., Saks et al., 2012) of Middle Weichselian age. This could be explained by the possible erosion of these younger sediments in the central part of the Zemgale Ice Lobe, which advanced several times in the Late Weichselian. Glacial erosion was less effective elsewhere; sediments deposited during the Middle Weichselian are known from other localities in Latvia, where glacial erosion was weaker. For example, OSL dates (Zelčs et al., 2011) from sandy deposits found in an interlobate position at the Kažoki site (see Fig. 1 for location) and located on the eastern slope of the Eastern Kursa Upland, adjacent to the study area, yield ages of $26.9 \pm 4.4 \mathrm{ka}$ and $29.4 \pm 4.7 \mathrm{ka}$. These younger, extensively folded and thrusted outwash deposits were preserved during the advance of the Zemgale Ice Lobe; this is most likely due to weaker glacial erosion on the periphery of the Eastern Kursa Upland.

Finally, ESR dates from Portlandia arctica shells from till in the banks of the Daugava River, Daugmales Tomēni site, provide additional stratigraphical evidence for Pleistocene deposition in the CLL (Molodkov et al., 1998). The ESR ages
$(86.0 \pm 6.8 \mathrm{ka}, 105.0 \pm 9.2 \mathrm{ka})$ support the clear pattern of ice-free conditions during the Early Weichselian as noted in this study. This is because $P$. arctica shells come from Early Weichselian interstadial marine deposits that were displaced from their origin in the Gulf of Riga by the Zemgale Lobe during the last glaciation (Molodkov et al., 1998, Zelčs et al., 2011).

\section{CONCLUSIONS}

Our study demonstrates the extent to which luminescence dating can contribute to deeper understanding of the history of the largely unstudied sandy deposits overlain by subglacial till of the Late Weichselian in central Latvia. Three OSL ages from the area covered by the Zemgale Ice Lobe range between $84 \pm 9 \mathrm{ka}$ and $112 \pm 11 \mathrm{ka}$, corresponding to an Early Weichselian age (MIS 5), and are supported by unpublished OSL ages from nearby sites (unpublished data; Oinonen and Eskola, 2009). The OSL dating results obtained demonstrate ice-free conditions during the Early and Middle Weichselian, when deposition of sandy sediments occurred in central Latvia. We found no Middle Weichselian age deposits in the Central Latvian Lowland and suppose that they could possibly have been eroded during the advances of the Zemgale Ice Lobe in the Late Weichselian, as this area was subject to considerable glacial erosion. However, Middle Weichselian (MIS 3) deposits (one sample; $44 \pm 10 \mathrm{ka}$ ) were found in the Nereta Quarry, which is located in the glaciotectonised ice-marginal succession next to the interlobate area.

Acknowledgements. The research was partially supported by the Swedish Institute, project 00365.2014 to E. Kalińska-Nartiša, and by the University of Latvia project "Climate change and sustainable use of natural resources" (No. AAP2016/B041) to K. Lamsters. Dr. E. Thamó-Bozsó (Geological and Geophysical Institute of Hungary) and an anonymous reviewer are thanked for valuable comments, which improved the manuscript.

\section{REFERENCES}

Alexanderson, H., Håkansson, L., 2014. Coastal glaciers advanced onto Jameson Land, East Greenland during the late glacial early Holocene Milne Land Stade. Polar Research, 33: $1-17$.

Alexanderson, H., Murray, A.S., 2012. Problems and potential of OSL dating Weichselian and Holocene sediments in Sweden. Quaternary Science Reviews, 44: 37-50.

Arnold, L.J., Roberts, R.G., 2009. Stochastic modelling of multi-grain equivalent dose (De) distributions: implications for OSL dating of sediment mixtures. Quaternary Geochronology, 4: 204-230

Arnold, L.J., Bailey, R.M., Tucker, G.E., 2007. Statistical treatment of fluvial dose distributions from southern Colorado arroyo deposits. Quaternary Geochronology, 2: 162-167.

Āboltiņš, O., 1963. Gorizonty verkhney moreny Zemgalyskoy ravniny i vopros o formirovanii Linkuvskoy konechnoy moreny (in Russian). In: Ucheniye zapiski aspirantov Latviyskogo Gosudarstvennogo Universiteta im. P. Stuchki (ed. N.S. Temnikova), 1: 5-17.

Āboltinš̌, O., 1989. Glaciostruktura i lednikoviy morfogenez (in Russian). Zinātne, Rîga.
Āboltinš, O., Vaitekunas, P., Danilāns, I., Karukapp, R., Klive, G., Raukas, A., Roshko, L., Chebotareva, N.S., Yanke, V., 1977. The Baltic ice stream. In: The structure and dynamics of the last ice sheet of Europe (ed. N.S. Chebotareva): 17-44. Nauka, Moscow.

Ballarini, M., Wallinga, J., Wintle, A.G., Bos, A.J.J., 2007. A modified SAR protocol for optical dating of individual grains from young quartz samples. Radiation Measurements, 42: 360-369.

Baltrūnas, V., Karmaza, B., Dundulis, K., Gadeikis, S., Račkauskas, V., Šinkūnas, P., 2005. Characteristic of till formation during Baltija (Pomeranian) stage of the Nemunas (Weichselian) glaciation in Lithuania. Geological Quarterly, 49 (4): 417-428.

Baltrūnas, V., Šeirienè, V., Molodkov, A., Zinkutè, R., Katinas, V., Karmaza, B., Kisielienè, D., Petrošius, R., Taraškevičius, R., Piličiauskas, G., Schmölcke, U., Heinrich, D., 2013. Depositional environment and climate changes during the late Pleistocene as recorded by the Netiesos section in southern Lithuania. Quaternary International, 292: 136-149.

Banerjee, D., Murray, A. S., Bøtter-Jensen, L., Lang, A. 2001. Equivalent dose estimation using a single aliquot of polymineral fine grains. Radiation Measurements, 33: 73-94. 
Bøtter-Jensen, L., Bulur, E., Duller, G.A.T., Murray, A.S., 2000 Advances in luminescence instrument systems. Radiation Measurements, 32: 523-528.

Brangulis, A.J., Kuršs, V., Misāns, J., Stinkulis, G., 1998. Geological Map of Latvia, Scale 1:500,000. Geological Structure Description (in Latvian). State Geological Survey, Rīga.

Danilāns, I., 1973. Chetvertichnye otlozheniya Latvii (in Russian). Zinātne, Rīga.

Dreimanis, A., 1935. The rock deformations, caused by inland ice, on the left bank of Daugava at Dole Island, Near Rīga in Latvia (in Latvian with English summary). Gulbis, Rīga.

Dreimanis, A., 1992. Downward injected till wedges and upward injected till dikes. Sveriges Geologiska Undersökning, 4: 91-96.

Dreimanis, A., Zelčs, V., 1995. Pleistocene stratigraphy of Latvia In: Glacial Deposits in North-East Europe (eds. J. Ehlers, S Kozarski and P.L. Gibbard): 105-113. Balkema, Rotterdam/Brookfield.

Dreimanis, A., Zelčs, V., 1998. Daugmale ribbed moraine: introduction to STOP 1. Stop 1: Internal structure and morphology of glaciotectonic landforms at Daugmale. In: The INQUA Peribaltic Group Field Symposium on Glacial Processes and Quaternary Environment in Latvia, May 25-31, 1998, Rīga, Latvia. Excursion guide (ed. V. Zelčs): 3-14. University of Latvia, Rīga.

Dreimanis, A., Zelčs, V., 2004. STOP 13: The River Daugava Bluff Sections at the Ridge Kalnmuiža and Hill Krančkalns. In: International Field Symposium on Quaternary Geology and Modern Terrestrial Processes, Western Latvia, September 12-7, 2004 Excursion Guide (ed. V. Zelčs): 70-75. University of Latvia, Rīga.

Duller, G.A.T., 2003. Distinguishing quartz and feldspar in single grain luminescence measurements. Radiation Measurements, 37: 161-165.

Duller, G.A.T., 2008. Single-grain optical dating of Quaternary sediments: why aliquot size matters in luminescence dating. Boreas, 37: 589-612.

Eyles, N., Eyles, C.H., Miall, A.D., 1983. Lithofacies types and vertical profile models: an alternative approach to the description and environmental interpretation of glacial diamict and diamictite sequences. Sedimentology, 30: 393-410.

Fuchs, M., Owen, L.A., 2008. Luminescence dating of glacial and associated sediments: review, recommendations and future directions. Boreas, 37: 636-659.

Gaigalas, A., 1995. Glacial history of Lithuania. In: Glacial Deposits in North-East Europe (eds. J. Ehlers, S. Kozarski and P.L. Gibbard): 127-137. Balkema, Rotterdam.

Gaigalas, A., Marcinkevičius, V., 1982. Bedded structure and genesis of forms of hollow-ridge glacial relief in North Lithuania. Geologija, 3: 69-79.

Galbraith, R.F., Roberts, R.G., Laslett, G.M., Yoshida, H., Olley, J.M., 1999. Optical dating of single and multiple grains of quartz from Jinmium rock shelter, Northern Australia: Part I, Experimetal design and statistical models. Archaeometry, 41 339-364.

Ginters, G., 1978. Moreny Yuzhno-Kurzemskoy nizmennosti. In: Problemy morfogeneza relyefa i paleogeografii Latvii (eds. O Āboltinsš, V. Klāne and G. Eberhards) (in Russian): 99-107. Latvian State University im. P. Stuchki, Rīga.

Guobytè, R., 2004. A brief outline of the Quaternary of Lithuania and the history of its investigation. In: Extent and Chronology of Glaciations, 1 (Europe) (eds. J. Ehlers and P.L. Gibbard) 245-250. Elsevier, Amsterdam.

Guobytè, R., Satkūnas, J., 2011. Pleistocene glaciations in Lithuania. In: Quaternary Glaciations - Extent and Chronology: A Closer Look, 15 (eds. J. Ehlers, P.L. Gibbard and P.D. Hughes) 231-246. Elsevier, Amsterdam.

Holmlund, P., Fastook, J.L., 1995. A time dependent glaciological model of the Weichselian ice sheet. Quaternary International, 27: $53-58$

Jacobs, Z., 2008. Luminescence chronologies for coastal and marine sediments. Boreas, 37: 508-535.
Jain, M., Bøtter-Jensen, L., Singhvi, A.K., 2003. Dose evaluation using multiple-aliquot quartz OSL: Test of methods and a new protocol for improved accuracy and precision. Radiation Measurements, 37: 67-80.

Juškevičs, V., 2000. Quaternary Geological Map (in Latvian with English summary). In: Geological map of Latvia, scale 1:200,000. Sheet 43 - Rīga, Sheet 53 - Ainaži. Explanatory Notes and Maps (eds. O. Āboltiņš and V. Kuršs). State Geological Survey, Rīga.

Juškevičs, V., 2001. Quaternary Geological Map (in Latvian with English summary). In: Geological map of Latvia, scale 1:200,000. Sheet 32 - Jelgava. Explanatory Notes and Maps (eds. O. Āboltiņš and A. Brangulis). State Geological Survey, Rīga.

Kalińska-Nartiša, E., Nartišs, M., Thiel, C., Buylaert, J.-P., Murray, A.S., 2015a. Late-glacial to Holocene aeolian deposition in northeastern Europe - The timing of sedimentation at the lisaku site (NE Estonia). Quaternary International, 357: 70-81.

Kalińska-Nartiša, E., Thiel, C., Nartišs, M., Buylaert, J.-P., Murray, A.S., 2015b. Age and sedimentary record of inland aeolian sediments in Lithuania, NE European Sand Belt. Quaternary Research, 84: 82-95.

Kalińska-Nartiša, E., Thiel, C., Nartišs, M., Buylaert, J.-P., Murray, A.S., 2016. The north-eastern aeolian "European Sand Belt" as potential record of environmental changes: a case study from Eastern Latvia and Southern Estonia. Aeolian Research, 22: $59-72$

Kalm, V., 2006. Pleistocene chronostratigraphy in Estonia, southeastern sector of the Scandinavian glaciation. Quaternary Science Reviews, 25: 960-975.

Kalm, V., 2012. Ice-flow pattern and extent of the last Scandinavian Ice Sheet southeast of the Baltic Sea. Quaternary Science Reviews, 44: 51-59.

Kalm, V., Raukas, A., Rattas, M., Lasberg, K., 2011. Pleistocene glaciations in Estonia. Developments in Quaternary Science, 15: 95-104.

King, G.E., Robinson, R.A.J., Finch, A.A., 2014. Towards successful OSL sampling strategies in glacial environments: deciphering the influence of depositional processes on bleaching of modern glacial sediments from Jostedalen, Southern Norway. Quaternary Science Reviews, 89: 94-107.

Klasen, N., Fiebig, M., Preusser, F., Reitner, J.M., Radtke, U., 2007. Luminescence dating of proglacial sediments from the Eastern Alps. Quaternary International, 164-165: 21-32.

Kuhns, C.K., Agersnap Larsen, N., McKeever, S.W.S., 2000. Characteristics of LM-OSL from several different types of quartz. Radiation Measurements, 32: 413-418.

Lamsters, K., 2012. Drumlins and related glaciogenic landforms of the Madliena Tilted Plain, Central Latvian Lowland. Bulletin of the Geological Society of Finland, 84: 45-57.

Lamsters, K., Zelčs V., 2015. Subglacial bedforms of the Zemgale Ice Lobe, SE Baltic. Quaternary International, 386: 42-54.

Lasberg, K., Kalm, V., 2013. Chronology of Late Weichselian glaciation in the western part of the East European Plain. Boreas, 42 995-1007.

Levkov, E., 1980. Glaciotektonika (in Russian). Nauka i tekhnika, Minsk.

Lukas, S., Spencer, J.Q.G., Robinson, R.A.J., Benn, D.I., 2007 Problems associated with luminescence dating of Late Quaternary glacial sediments in the NW Scottish Highlands. Quaternary Geochronology, 2: 243-248.

Mangerud, J., 1991. The last interglacial/glacial cycle in northern Europe. In: Quaternary Landscapes (eds. L.C.K. Shane and E.J. Cushing): 38-75. University of Minnesota Press, Minneapolis.

Mehta, M., Dobhal, D., Pratap, B., Majeed, Z., Gupta, A. K., Srivastava, P., 2014. Late Quaternary glacial advances in the Tons River Valley, Garhwal Himalaya, India and regional synchronicity. The Holocene, 24: 1336-1350. 
Meirons, Z., 1986. Stratigraphy of Pleistocene deposits in Latvia (in Russian). In: Issledovaniya lednikovykh obrazovaniy Pribaltiki (eds. O. Kondratiene and A. Mikalauskas): 69-81. AN Litovskoi SSR, Vilnius.

Meirons, Z., 2002. Quaternary Geological Map. In: Geological map of Latvia, scale 1:200,000. Sheet 33 - Ogre. Explanatory Notes and Maps (eds. O. Āboltingš and A. Brangulis) (in Latvian with English summary). State Geological Survey, Rīga.

Meirons, Z., Punning, M.J., Hütt, G., 1981. Results obtained through the TL dating of South-East Latvian Pleistocene deposits (in Russian with English summary). Eesti NSV Teaduste Akadeemia Toimetised, Geologia 30: 28-33.

Miall, A.D., 1978. Lithofacies types and vertical profile models in braided river deposits: a summary. Canadian Society of Petroleum Geologists Memoir, 5: 597-604.

Mironovs, G., Vācele, V., Vasiljeva, V., Karpickis, V., Ķipēna, M., 1962. Geologicheskoye stroyeniye i gidrogeologicheskoye usloviya teritorii lista O-35-XXVI (in Russian). Otchot Vidzemskoy kompleksnoy GSP po rabotam, 1959-1960 g., I. Latvian Geological Board, Rīga.

Molodkov, A., Dreimanis, A., Ảboltinš̌, O., Raukas, A., 1998. The age of Portlandia arctica shells from glacial deposits of Central Latvia: an answer to a controversy on the age and genesis of their enclosing sediments. Quaternary Geochronology, 17: 1077-1094

Molodkov, A., Bitinas, A., Damušytè, A., 2010. IR-OSL studies of till and inter-till deposits from the Lithuanian Maritime Region. Quaternary Geochronology, 5: 263-268.

Murray, A.S., Olley, J.M., 2002. Precision and accuracy in the optically stimulated luminescence dating of sedimentary quartz: a status review. Geochronometria, 21: 1-16.

Murray, A.S., Wintle, A.G., 2000. Luminescence dating of quartz using an improved single-aliquot regenerative-dose protocol. Radiation Measurements, 32: 57-73.

Murray, A.S., Marten, R., Johnston, A., Martin, P., 1987. Analysis for naturally occurring radionuclides at environmental concentrations by gamma spectrometry. Journal of Radioanalytical and Nuclear Chemistry, 115: 263-288.

Oinonen, M., Eskola, K.O., 2009. Research report - Luminescence dating of Latvian samples, Purchase identification No. LU 2008/l-269, part 1 (16 samples), Helsinki, p. 5.

Olley, J.M., Murray, A.S., Roberts, R.G., 1996. The effects of disequilibria in the uranium and thorium decay chains on burial dose rates in fluvial sediments. Quaternary Science Reviews, 15: 751-760.

Rattas, M., Kalm, V., Kihno, K., Liivrand, E., Tinn, O., Tänavsuu-Milkeviciene, K., Sakson, M., 2010. Chronology of Late Saalian and Middle Weichselian episodes of ice-free lacustrine sedimentation recorded in the Arumetsa section, southwestern Estonia. Estonian Journal of Earth Sciences, 59: $125-140$.

Raukas, A., Stankowski, W.T.J., Zelčs, V., Šinkunas, P., 2010. Chronology of the last deglaciation in the South-Eastern Baltic Region on the basis of recent OSL dates. Geochronometria, 36: 47-54.

Rinterknecht, V.R., Clark, P.U., Raisbeck, G.M., Yiou, F., Bitinas, A., Brook, E J., Marks, L., Zelčs, V., Lunkka, J.-P., Pavlovskaya, I.E., Piotrowski, J.A., Raukas, A., 2006. The last deglaciation of the southeastern sector of the Scandinavian Ice Sheet. Science, 311: 1449-1452.

Rinterknecht, V.R., Bitinas, A., Clark, P.U., Raisbeck, G.M., Yiou, F., Brook, E.J., 2008. Timing of the last deglaciation in Lithuania. Boreas, 37: 426-433.

Roberts, H.M., 2006. Optical dating of coarse-silt sized quartz from loess: Evaluation of equivalent dose determinations and SAR procedural checks. Radiation Measurements, 41: 923-929.

Rodnight, H., Duller, G.A.T., Wintle, A.G., Tooth, S., 2006. Assessing the reproducibility and accuracy of optical dating of fluvial deposits. Quaternary Geochronology, 1: 109-120.
Saks, T., Kalvāns, A., Zelčs, V., 2012. OSL dating of Middle Weichselian age shallow basin sediments in Western Latvia, Eastern Baltic. Quaternary Science Reviews, 44: 60-68.

Satkūnas, J., Grigienè, A., 2012. Eemian-Weichselian palaeoenvironmental record from the Mickūnai glacial depression (Eastern Lithuania). Geologija, 54: 35-51.

Satkunas, J., Grigiene, A., Jusiene, A., Damusyte, A., Mazeika, J., 2009. Middle Weichselian paleolacustrine basin in the Venta river valley and vicinity (northwest Lithuania), exemplified by the Purviai outcrop. Quaternary International, 207: 14-25.

Satkunas, J., Grigiene, A., Buynevich, I.V., Taminskas, J., 2013. A new Early-Middle Weichselian palaeoenvironmental record from a lacustrine sequence at Svirkanciai, Lithuania. Boreas, 42: 184-193.

Savvaitov, A., Straume, J., 1963. On the question of twin strata in the moraine of Valdai glaciation in the area between the lower reaches of the rivers Daugava and Gauja (in Russian with English summary). In: Questions on Quaternary Geology, 2 (ed. I. Danilāns): 71-86. Academy of Sciences of Latvian SSR, Rīga.

Straume, J., 1979. Geomorphology (in Russian). In: Geologicheskoye stroyenie i poleznye iskopayemye Latvii (eds. J. Misāns, A. Brangulis, I. Danilāns and V. Kuršs): 297-439. Zinātne, Rīga.

Svendsen, J.I., Alexanderson, H., Astakhov, V.I., Demidov, I, Dowdeswell, J.A, Funderf, S., Gataullin, V., Henriksena, M., Hjort, C., Houmark-Nielsen, M., Hubbertenk, H.W, Ingólfsson, Ó., Jakobsson, M., Kjæri, K.H., Larsen, E., Lokrantz, H., Lunkka, J.P., Lyså, A., Mangerud, J., Matiouchkov, A., Murray, A., Möller, P., Niessens, F., Nikolskaya, O., Polyak, L., Saarnisto, M., Siegert, C., Siegert, M.J., Spielhagen, R.F., Steins, R., 2004. Late Quaternary ice sheet history of northern Eurasia. Quaternary Science Reviews, 23: 1229-1271.

Thomas, D.S.G., Burrough, S.L., 2013. Luminescence-based dune chronologies in southern Africa: analysis and interpretation of dune database records across the subcontinent. Quaternary International, 21: 825-836.

Thrasher, I.M., Mauz, B., Chiverrell, R.C., Lang, A., 2009. Luminescence dating of glaciofluvial deposits: a review. Earth-Science Reviews, 97: 133-146.

Wallinga, J., 2002. On the detection of OSL age overestimation using single-aliquot techniques. Geochronometria, 21: 17-26.

Weckwerth, P., Przegiętka, K.R., Chruścińska, A., Pisarska-Jamroży, M., 2013. The relation between optical bleaching and sedimentological features of fluvial deposits in the Toruń Basin (Poland). Geological Quarterly, 57 (1): 31-44.

Wintle, A.G., 2008. Luminescence dating: where it has been and where it is going. Boreas, 37: 471-482.

Wintle, A.G., Murray, A.S., 2006. A review of quartz optically stimulated luminescence characteristics and their relevance in single-aliquot regeneration dating protocols. Radiation Measurements, 41: 369-391.

Wyshnytzky, C.E., Rittenour, T.M., Summa, M., Thackray, G., 2015. Luminescence dating of late Pleistocene proximal glacial sediments in the Olympic Mountains, Washington. Quaternary International, 362: 116-123.

Zelčs, V., 1993. Glaciotectonic landforms of divergent type glaciodepressional lowlands. Dissertation work synthesis. University of Latvia, Rīga.

Zelčs, V., Markots, A., 2004. Deglaciation history of Latvia. In: Quaternary Glaciations - Extent and Chronology. Part I: Europe (eds. J. Ehlers and P.L. Gibbard): 225-243. Elsevier, Amsterdam.

Zelčs, V., Markots, A., Nartišs, M., Saks, T., 2011. Chapter 18: Pleistocene glaciations in Latvia. Developments in Quaternary Science, 15: 221-229. 